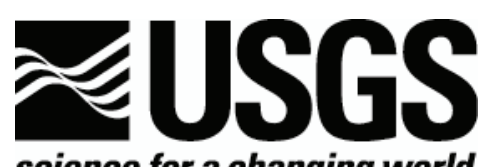

science for a changing world

\title{
Aqueous Geochemical Data from the Analysis of Stream-Water Samples Collected in June and July 2005 - Taylor Mountains 1:250,000 Scale Quadrangle, Alaska
}

By Bronwen Wang, Seth Mueller, Sarah Stetson, Elizabeth Bailey, and Greg Lee.

Any use of trade, firm, or product names is for descriptive purposes only and does not imply endorsement by the U.S. Government

Open-File Report 2006-1361 


\section{U.S. Department of the Interior}

\section{U.S. Geological Survey}

U.S. Geological Survey, Reston, Virginia 2006

For product and ordering information:

World Wide Web: http://www.usgs.gov/pubprod

Telephone: 1-888-ASK-USGS

For more information on the USGS - the Federal source for science about the Earth, its natural and living resources, natural hazards, and the environment:

World Wide Web: http://www.usgs.gov

Telephone: 1-888-ASK-USGS 


\title{
Aqueous Geochemical Data From the Analysis of Stream- Water Samples Collected in June and July 2005-Taylor Mountains 1:250,000 Scale Quadrangle, Alaska
}

\author{
By Bronwen Wang, Seth Mueller, Sarah Stetson, Elizabeth Bailey, and Greg Lee
}

\section{Abstract}

We report on the chemical analysis of water samples collected from the Taylor Mountains 1:250,000-scale quadrangle. Parameters for which data are reported include $\mathrm{pH}$, conductivity, water temperature, major cation and anion concentrations, trace-element concentrations, and dissolved organic-carbon concentrations. Samples were collected as part of a multiyear U.S. Geological Survey project "Geologic and Mineral Deposit Data for Alaskan Economic Development." Data presented here are from samples collected in June and July of 2005. The data are being released at this time with minimal interpretation. This is the second release of aqueous geochemical data from this project; 2004 aqueous geochemical data were published previously (Wang and others, 2006). The data in this report augment but do not duplicate or supersede the previous data release. Site selection was based on a regional sampling strategy that focused on first- and second-order drainages. Water sample site selection was based on landscape parameters that included physiography, wetland extent, lithological changes, and a cursory field review of mineralogy from pan concentrates. Stream water in the Taylor Mountians quadrangle is dominated by bicarbonate (HCO3-), though in a few samples more than 50 percent of the anionic charge can be attributed to sulfate ( $\mathrm{SO} 42-$ ). The major-cation chemistry ranges from $\mathrm{Ca} 2+/ \mathrm{Mg} 2+$ dominated to a mix of $\mathrm{Ca} 2+/ \mathrm{Mg} 2+/ \mathrm{Na}++\mathrm{K}+$. In general, good agreement was found between the major cations and anions in the duplicate samples. Many trace elements in these samples were at or near the analytical method detection limit, but good agreement was found between duplicate samples for elements with detectable concentrations. With the exception of a total mercury concentration of $0.33 \mathrm{ng} / \mathrm{L}$ detected in a field blank, field blank major-ion and trace-elements concentrations were below detection.

\section{Introduction}

Geological, geochemical, and geophysical data are important to the development of mineral resources in Alaska. However, even at a reconnaissance scale of 1:250,000, less than half of Alaska has adequate data to assess the undiscovered mineral resource potential. Government agencies and private industry have requested the collection of new geological data and in response the U.S. Geological Survey initiated the "Geologic and Mineral Deposit Data for Alaskan Economic Development" project with the goal of obtaining geological data for data-poor regions of the state.

Southwestern Alaska, which includes the Taylor Mountains quadrangle (fig.1), is a region with only minimal geologic data available (Miller, 2006). However, based on the limited data and known mineral prospects, the region is thought to have a high potential for undiscovered mineral resources. Therefore, we initially focused data collection in this area. This is the second release of aqueous geochemical data from this project; the 2004 aqueous geochemical data were released previously (Wang and others, 2006). The data released in this report augment but do not duplicate or supersede the previous data release. Data from the 2005 sample collection are being released at this time with minimal interpretation.

\section{Methods}

The water sampling sites represent a subset of sites used for sediment sampling for the overall project goal. Site selection was based on a regional sampling strategy that focused on first- and second- order streams (fig.1). Water sampling site selection was also based on landscape parameters that included physiography, wetland extent, lithological changes, and a cursory field review of the mineralogy in the pan concentrate samples. Stream $\mathrm{pH}$, conductivity, and temperature were measured on site. All three values were measured directly in the stream using standard $\mathrm{pH}$ meters, conductivity meters, and submergible thermometers. The $\mathrm{pH}$ meters were

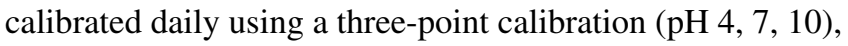
and $\mathrm{pH}$ standards were used in the field to monitor the performance of the $\mathrm{pH}$ probe. The conductivity meters were checked and calibrated daily with a $1430 \mu \mathrm{S} / \mathrm{cm}$ standard. 
Dip-composite water samples were collected using telfon collection bottles. The collection bottles were cleaned in a boiling nitric-acid bath prior to field deployment (Olson and DeWild, 1999). In the field, the sample bottles were carried, capped in clean plastic-resealable bag, in the samplers' backpacks. The sample collection bottle was rinsed with copious amounts of native water prior to sample collection. Sampling consisted of dipping the collection bottle at several locations across the stream, upstream of all other sampling activities. Samplers wore disposable gloves during the sampling and sample processing. Waters for major- and trace-element analysis were filtered immediately after collection through a $0.45 \mu \mathrm{m}$ capsule filter, using a peristaltic pump, into high density polyethylene bottles. Samples for major cation $(\mathrm{Ca} 2+$, $\mathrm{Mg} 2+, \mathrm{K}+, \mathrm{Na}+$ ) and trace-element analysis were preserved with $0.5 \mathrm{ml}$ ultra-high-purity concentrated HNO3. Samples for alkalinity and major anion (SO42-, Cl-, F-, NO3-) analysis were filtered but not acidified. A single sample was taken for both low-level total and methyl-mercury analysis, and a final sample was collected for dissolved organic carbon (DOC) analysis. The mercury and DOC samples were collected as above. However, the total- and methyl-mercury sample was not filtered and was simply transferred from the collection bottle to a sterile polyethylene terephthalate copolyester (PETG) bottle. PETG bottles are appropriate for low-level mercury analysis (Dave Kabbenhoft, oral commun.). The mercury sample was preserved with $5 \mathrm{ml}$ of 5 percent mercury-free hydrochloric acid. Samples for DOC were filtered through a $0.45 \mu \mathrm{m}$ baked-glass fiber filter into an amber glass bottle. The mercury samples refrigerated and then shipped, on ice, to the USGS Wisconsin Science Center Mercury Research Laboratory in Middleton, Wis., for analysis. The DOC samples were refrigerated and then shipped, on ice, to the USGS National Research Program's Carbon Research Laboratory in Boulder, Colo., for DOC analysis.

Samples for major- and trace- element analysis were shipped to the USGS Minerals Program Denver laboratories for analysis. Major cations $(\mathrm{Ca} 2+, \mathrm{Mg} 2+, \mathrm{K}+, \mathrm{Na}+)$ and trace element concentrations were determined by inductively coupled plasma mass spectrometry (ICP-MS) (Lamothe and others, 2002) and major anions (SO42-, Cl-, F-, NO3-) by ion chromatography (IC) (Theodorakos and others, 2002). Alkalinity was determined using a preset endpoint ( $\mathrm{pH} 4.5)$ autotitration system (Theodorakos, 2002). Laboratory procedures require instrument calibration with an appropriate standard and analysis of standard reference materials where appropriate. In general, the instrument calibration and quality control procedures for the laboratory are (1) daily hardware and software checks to insure the instrument and its components are working properly; (2) calibration of the instrument using appropriate standards; the calibration standards used contain all the elements that are reported from the analysis; (3) standard reference materials run where appropriate; for water samples, the standard reference materials are acquired from the U.S. Geological Survey Water Resource Discipline and information regarding these reference materials is at
http://bqs.usgs.gov/SRS/ (last accessed Nov. 15 , 2006); (4) samples are analyzed with every tenth sample a calibration check solution (that is, a calibration standard run as a sample), and after every 20 samples, the instrument is recalibrated and standard reference materials are analyzed; and (5) each group of samples concludes with a standard reference material analysis (Lamothe, oral commun.).

Elements determined by ICP-MS and IC are censored to the lower limit of determination (LLD) for the method as determined in Lamothe and others (2002) and Theodorakos and others (2002). The method LLD is defined as 5-times the standard deviation of the instrument response on a blank solution. All values below the LLD are reported as less than the LLD. In some instances, the LLD has changed since the methods were publish and the LLD values used in this data release are given in table 1 . As a result of instrumental variations and matrix interferences, the data may be censored higher than the method LLD by the analyst.

Mercury concentrations were determined using cold-vapor atomic-fluorescence spectrometry (DeWild and others, 2002; Olson and DeWild, 1999), and DOC was determined by heat assisted persulfate oxidation with quantification by means of nondispersive infrared detection (Olson, and De Wild, 1997). Laboratory procedures for ensuring total and methyl-mercury and DOC data quality are given in Olson and DeWild (1999) and Olson and DeWild (1997), respectively. Method performance and method detection limits for the total and methylmercury are given in Olson and DeWild (1999) and DeWild and others (2002). Theodorakas (2002) details the uncertainty assignment information for the alkalinity determination method.

The analytical data are stored in the USGS National Geochemical Database maintained by the Minerals Program in Denver, Colo. (contact Dave Smith), and the USGS Wisconsin Science Center Mercury Research Laboratory database (contact John DeWild). Data in the appendices of this report are the complete analytical data available for these samples.

\section{Data Summary}

Major- and trace- element data are summarized in tables 1 and 2 , and the complete analytical data are presented in the appendices. Of the trace elements analyzed, $\mathrm{Ag}, \mathrm{Be}, \mathrm{Bi}, \mathrm{Cd}$, $\mathrm{Ga}, \mathrm{Ge}, \mathrm{Lu}$ were not detected in the water samples. Minimum and maximum concentrations, mean, and median values of the elements in water are given in table 1, however, summary statistics were not calculated if the number of qualified values exceeded 25 percent of the samples (table 1). For elements with qualified values summary statistics were calculated using the Kaplan-Meier method for censored data as detailed in Helsel (2005).

The major anion chemistry of the samples collected in 2005 from the Taylor Mountains quadrangle is dominated by bicarbonate $\left(\mathrm{HCO}_{3}^{-}\right.$, calculated from the alkalinity) though in a few samples more than 50 percent of the anionic charge can 
be attributed to sulfate ( $\mathrm{SO}_{4}^{2-}$ ). The major-cation chemistry ranges from $\mathrm{Ca}^{2+} / \mathrm{Mg}^{2+}$-dominated water to a mix of $\mathrm{Ca}^{2+} /$ $\mathrm{Mg}^{2+} / \mathrm{Na}^{+}+\mathrm{K}^{+}$water (fig. 2).

Duplicate samples were collected for trace-element and major-ion analysis at sites 05TA403, 05TA475, 05TA512, 04TA111, 05TA561, 05TA578, 05TA648, 05TA714, and 05 TA736 (table 2). Duplicate samples were taken for total and methyl-mercury and DOC analysis at site 05TA403. Good agreement was found between the major cation in the duplicate samples $\left(\mathrm{Ca}^{2+} 1\right.$ to 5 percent difference, $\mathrm{Mg}^{2+} 0.3$ to 3 percent difference, $\mathrm{Na}^{+} 0.3$ to 5 percent difference, $\mathrm{K}^{+}$no difference; table 2). Generally good agreement was found between the major anions. However, a 50 percent difference was found for $\mathrm{Cl}^{-}, \mathrm{F}^{-}$, and $\mathrm{SO}_{4}{ }^{2-}$ between duplicates of $05 \mathrm{TA} 403$ (table 2). Many trace elements were at or near the detection limit of the method used in these samples; however, good agreement was found between duplicate samples for elements with detectable concentrations. Major-ion concentrations were below detection in all field blanks, and generally, the trace-element concentrations were below detection; however, total mercury was detected in the blank at $0.33 \mathrm{ng} / \mathrm{L}$ (table 2 ).

\section{References Cited}

DeWild, J.F., Olson, M.L., and Olund, S.D., 2002, Determination of methyl mercury by aqueous phase ethylation, followed by gas chromatographic separation with cold vapor atomic fluorescence detection: U. S. Geological Survey Open-File Report 01-445 [http://infotrek.er.usgs.gov/mercury/methods.html (last accessed Nov. 15, 2006)].

Helsel, D.R., 2005, Nondetects and data analysis-statistics for censored environmental data: Wiley-Interscience, Hoboken, New Jersey, 250 p.

Lamothe, P.J., Meier, A.L., Wilson, S.A., 2002, The determination of fourty-four elements in aqueous samples by inductively coupled plasma-mass specrtometry, in Taggart, J.E. ed., Analytical methods for chemical analysis of geologic and other material: U.S. Geological Survey Open-File Report 02-223 [http://pubs.usgs.gov/of/2002/ofr-02-0223/ (last accessed Nov. 15, 2006)].
Miller, M.L., Bailey, E.A., Beischer, G.A., Bradley, D.C., Bundtzen, T.K., Goldfarb, R.J., Karl, S.M., Saltus, R.W., and Wang, B., 2006, USGS mineral resource studies in the Taylor Mountains quadrangle, southwestern Alaska-new "AMRAP": Journal of the Alaska Miners Association, v. 34 , no. 2, p. 1-15.

Olson, M.L., and DeWild, J.F., 1997, Standard operating procedure for the determination of dissolved organic carbon in water: USGS Wisconsin Science Center Mercury Laboratory Standard Operating Procedure 006, 9 p. [http://infotrek. er.usgs.gov/mercury/sop_6_port.htm\#0.0 (last accessed Nov. 15, 2006)].

Olson, M.L., and DeWild, J.F., 1999, Low-level collection techniques and species-specific analytical methods for mercury in water, sediment, and biota: U. S. Geological Survey Water Resources Investigations 99-4018-B, 11 p.

Theodorakos, P.M., 2002, Determination of total alkalinity using a preset endpoint ( $\mathrm{pH} 4.5$ ) autotitration system, in Taggart, J.E. ed., Analytical methods for chemical analysis of geologic and other material: U.S. Geological Survey Open-File Report 02-223 [http://pubs.usgs.gov/of/2002/ofr02-0223/ (last accessed Nov. 15, 2006)].

Theodorakos, P.M., d'Angelo, W.M., Ficklin, W.H., 2002, Floride, chloride, nitrate, and sulfate in aqueous solutions utilizing AutoSuppression chemically suppressed ion chromatography in Taggart, J.E., ed., Analytical methods for chemical analysis of geologic and other material: U.S. Geological Survey Open-File Report 02-223 [http://pubs. usgs.gov/of/2002/ofr-02-0223/ (last accessed Nov. 15, 2006)].

Wang, B., Mueller, S., Bailey, E., Lee, G., 2006, Aqueous geochemical data from the analysis of stream water samples collected in August 2004 - Taylor Mountains 1:250,00scale quadrangle, Alaska: U.S. Geological Survey OpenFile Report 2006-1175 [http://pubs.usgs.gov/of/2006/1175/ (last accessed Nov. 15, 2006)]. 


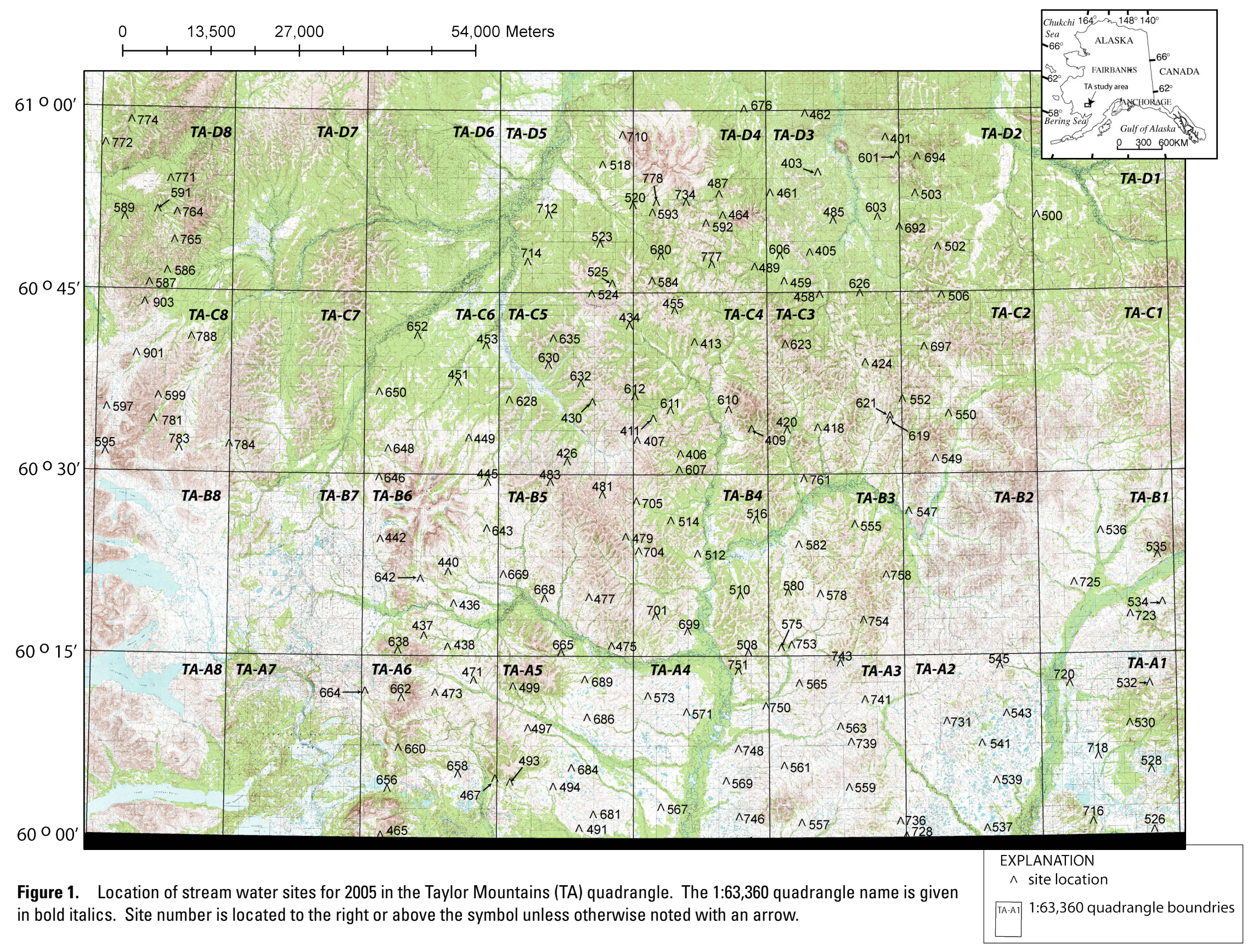

Figure 1. Location of stream water sites for 2005 in the Taylor Mountains (TA) quadrangle. The 1:63,360 quadrangle name is given

A-A $1: 63,360$ quadrangle boundries 


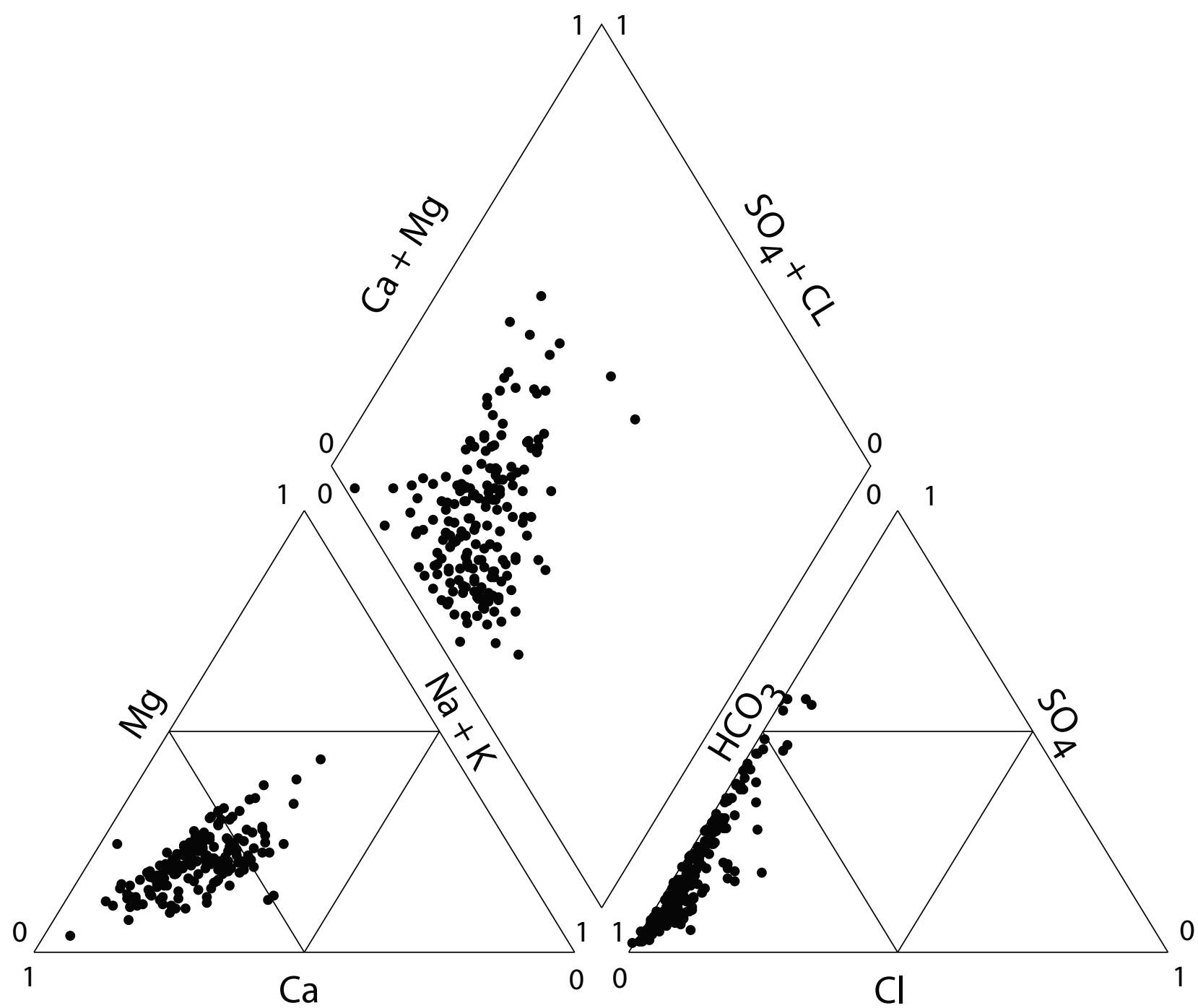

Figure 2. Tri-linear diagram showing the range of major-ion ratios in stream-water samples collected from the Taylor Mountains quadrangle. 